\title{
Teacher's Role in Developing Learner Autonomy: A Literature Review
}

\author{
Ligang $\operatorname{Han}^{1}$ \\ ${ }^{1}$ School of Foreign Languages, North China Electric Power University, Baoding, China \\ Correspondence: Ligang Han, School of Foreign Languages, North China Electric Power University, Baoding, Hebei, \\ China. Tel: 86-393-125-2856. E-mail: liganghan@163.com
}

Received: February 25, 2014 Accepted: March 28, 2014 Online Published: April 28, 2014

doi:10.5430/ijelt.v1n2p21 URL: http://dx.doi.org/10.5430/ijelt.v1n2p21

\begin{abstract}
Learner autonomy has become a hot topic in the research of foreign language education. However, it is the most difficult question to define learner autonomy and any answer to it is likely to be subjective. On the basis of expounding upon the different definitions concerning the research on autonomy in language teaching and learning, the focus of the present paper is on the teacher's roles in fostering learner autonomy. The roles that teachers are expected to play from the theoretical and empirical backgrounds are reviewed and the future research trend is explicated based on it.
\end{abstract}

Keywords: learner autonomy, teacher's role, foreign language education

\section{Introduction}

With the change from teacher-centeredness to learner-centeredness in education, learner autonomy (LA) has become a hot topic in the research of foreign language education. Most researchers and educators consider that it is one of the most important goals to foster LA (Broady \& Kenning, 1996; Benson, 1997; Benson 2004; Allford \& Pachler, 2007; Jiménez Raya \& Lamb, 2008). It is especially true for college English teaching in China. In 2007, the reformed College English Curriculum Requirements (CECR) is issued by the Higher Education Department of the Ministry of Education, providing the colleges and universities with the guidelines for English instruction to non-English major students. CECR states that the objective of College English is to develop students' ability to use English in an all-round way, especially in listening and speaking, so that in their future work and social interactions they will be able to exchange information effectively through both spoken and written channels, and at the same time they will be able to enhance their ability to study independently and improve their cultural quality so as to meet the needs of China's social development and international changes (Higher Education Department of the Ministry of Education, 2007). Besides, the traditionally teacher imparting the language and skills in class will be replaced by fostering students' ability to use the language and ability to learn independently.

In fact, developing LA has become an educational goal in modern languages education, not only at college and university level, but also a life goal for language learners. However, Benson $(2005 ; 2011)$ argues that the idea of autonomy often provokes strong reactions. To its critics, autonomy is an idealistic goal and its promotion a distraction from the real business of teaching and learning languages. To its advocates, autonomy is a precondition for effective learning; when learners succeed in developing autonomy, they will not only become better language learners but they also develop into more responsible and critical members of the community in which they live.

It is important to clarify what LA connotates before a detailed elaboration on the promoting process. Therefore, in this paper, on the basis of expounding upon the different definitions concerning the research on autonomy in language teaching and learning, the focus is upon the teacher's role in fostering LA. Based on a literature review on the roles that teachers are expected to play from the theoretical and empirical backgrounds, the future research trend is explicated.

\section{Research on Autonomy in Language Teaching and Learning}

The origins of the research on autonomy in language teaching and learning can be dated back to the mid-1970s (Holec, 1981; Gremmo \& Riley, 1995; Broady \& Kenning, 1996; Benson \& Voller, 1997; Littlewood, 1999; Lamb, 
\& Reinders, 2008; Smith, 2008). Until now, it is still of the remarkable interest in sense of self-regulation, motivation, socio-cultural theory and teacher development (Benson, 2005, 2011). Particular concerns include the ways in which conceptions of autonomy are changing with times, and the ways in which new conceptions of autonomy fit in with broader developments in language teaching and learning theory, educational practice and social thought.

\subsection{Definitions of Autonomy}

This is probably the single most difficult question to answer about autonomy in language learning and any answer to it is likely to be subjective. For Gardner and Miller (2002), there are three reasons for the difficulty in defining the concept of autonomy:

First, different writers have defined the concepts in different ways. Second, there are areas of ongoing debate and therefore definitions are continuing to mature as more discussion takes place. Third, these concepts have developed independently in different geographical areas and therefore they have been defined using different (but often similar) terminology. (p. 5)

There are a number of terms related to autonomy that can be distinguished from it in various ways. Most people now agree that autonomy and autonomous learning are not synonyms of, 'self-instruction', 'self-direction', 'self-access', 'distance learning', or 'out-of-class learning'.

\subsubsection{Self-instruction}

Self-instruction refers to "learning without a teacher" (Little, 1991: 3); or "learning without the direct control of a teacher" (Dickinson, 1987: 5). Benson (2006) defines this term from two senses. In the narrow sense, self-instruction refers to the use of printed or broadcast self-study materials. In a broader sense, it refers to situations in which learners undertake language study largely or entirely without the aid of teachers.

\subsubsection{Self-direction}

Self-direction can be defined as "a particular attitude to the learning task, where the learner accepts responsibilities for all the decisions concerned with his learning but does not necessarily undertake the implementation of those decisions" (Dickinson, 1987: 11), or "the process or the techniques used in directing one's own learning" (Holec, 1981: 14).

\subsubsection{Self-access}

Self-access refers to "learning from materials and facilities that are organized to facilitate learning; self-instruction in using these materials" (Dickinson, 1987: 11). The term is neutral as to how self-directed or other directed the learners are. Gardner and Miller' (2002) book on self-access is the most comprehensive work in this field. Since its publication, the difficulty of making self-access centers work independently of teacher-support for autonomy has become a prominent theme in the literature. There has also been a shift of attention from the organization of self-access centers to the integration of self-access learning with coursework (Benson, 2006).

\subsubsection{Distance Learning}

Distance learning is a way of organizing learners which usually only allows them to control over access (Lewis, 1995, cited in $\mathrm{Xu}, 2006$ ). Distance learning has began to merge with CALL through concepts such as 'online learning', 'cyber-schools', 'asynchronous learning networks' and 'telematics', in which issues of autonomy are less frequently discussed (White, 2003: 27, cited in Benson, 2006).

\subsubsection{Out-of-class Learning}

The term often narrowly used to refer to the efforts of learners taking classroom-based language courses to find opportunities for language learning and use outside class (Benson, 2006). Benson (2006) also points out that recent study suggests that students tend to engage in out-of-class activities more frequently than their teachers know, often showing considerable creativity in situations where opportunities for out-of-class learning appear to be limited.

In brief, these terms basically describe various ways and degrees of learning by oneself, whereas autonomy refers to abilities and attitudes (or whatever we think the capacity to control your own learning consists of) (Benson, 2005). The point is, then, that learning by oneself is not the same thing as having the capacity to learn by oneself. Also, autonomous learners may well be better than others at learning by themselves (hence the connection), but they do not necessarily have to learn by themselves.

The relationship between learning beyond the classroom and autonomy is complex. On the one hand, all the modes of learning discussed above involve autonomous learning as Dickinson (1987) defined it. On the other, they demand a capacity for autonomy as Holec (1981) and others have defined it. 
The definitions of LA have been changing with times, among which Holec's (1981) has remained the most widely cited definition in the world. "Ability" is often replaced by "capacity", while "take charge of" is often replaced by "take responsibility for" (Benson, 2011). It pays much attention to an attribute of learners rather than learning situation. In the context of foreign language learning, Holec (1981) defines autonomy as the ability to take charge of one's own learning. An autonomous learner is therefore a person who is capable of taking charge of his or her own learning. The role of the teacher for autonomous learners is to help them to assume the responsibility for making decisions of their learning in:

1) determining the objectives;

2) defining the contents and progressions;

3) selecting methods and techniques to be used;

4) monitoring the procedure of acquisition properly speaking (rhythm, time, place, etc);

5) evaluating what has been acquired. (p. 3)

\subsection{A Working Definition}

The heated debate about the definition of autonomy has taken in many literature works (Littlewood, 1999). For example, whether LA should be thought of as a kind of capacity or behavior; whether it is characterized by learner responsibility or learner control; whether it is a psychological phenomenon with political implications or a political right with psychological implications; and whether the development of LA depends on complementary teacher autonomy (Little, 1995; Sinclair \& Lamb, 2000).

From the two mainstream of views on LA, it is quite complex to conclude a simple definition. In the present research, we adopt and create a working definition of LA based on what is proposed by Shu and Zhuang (2008). LA has the following three important characteristics. Firstly, LA refers to language learner's attitude. Language learner is willing to take an active attitude towards his or her language study, and takes the initiative to be responsible for the study. Secondly, LA is viewed as capacity. Through learner training and teacher support, language learner can develop the capacity to learn independently. Last but not least, the development of LA can not be accomplished without supportive environment or context. Here environment includes the teacher's guidance, teaching and learning facilities, and learning materials. Based on the above discussion, we consider LA as the constructive process how language learners develop their autonomy within the supportive environment. To a large extent, language teacher plays a crucial role in the classroom teaching in fostering LA.

\section{Teacher's Role in Fostering LA}

Most teachers would agree that the goal and significance of teaching is to bring about changes in learners. And their aim is to do so effectively. However, Voller (1997) points out what those changes might be, and how they can be effectively brought about, are determined by a complex set of interrelated that depend upon what the learner and the teacher perceive their respective roles to be, and upon a set of decisions, both taken by them and imposed upon them, and experiences, both past and present, that they bring with them to any given learning situation. So complex is the relationship between theses factors that one feature of many methodologies of language learning is to ignore, or at least marginalize, the teacher's role. This has been true both of language acquisition theory and of some methods associated with language learning and the learner-centered classroom.

It is clear, therefore, from the above illustration that the teacher's role in fostering LA should be well considered and not be ignored.

\subsection{Theoretical Research on Teacher's Role in Fostering LA}

The teachers need to adjust their roles to help language learners to develop their autonomy, the roles which are expected to be distinct from old ones carried out in the traditional teaching context. Based on the research papers discussing teachers' roles in relation to the promotion of LA (Knowles, 1975; Higgs, 1988; Nunan, 1993; Voller, 1997), the following table (Table 1) is made to illustrate the teachers' roles in developing LA in the field of language teaching. 
Table 1. Teachers' role in fostering LA

\begin{tabular}{|c|c|}
\hline Authors & Teachers' role in fostering LA \\
\hline Knowles (1975) & Teachers act as facilitators, helpers or consultants. \\
\hline Higgs (1988) & $\begin{array}{l}\text { During the learning process, in order to help the student learn how to } \\
\text { learn independently and effectively, the teacher play the role of a } \\
\text { manager who creates a supportive and stimulating learning } \\
\text { environment, who is available as a resource person, who challenges } \\
\text { learners to achieve their potential and who helps learners to become } \\
\text { aware of institutional requirements and expectations associated with the } \\
\text { discipline in which they are studying. }\end{array}$ \\
\hline Nunan (1993) & $\begin{array}{l}\text { Teachers are changing their traditional roles and moving to new ones } \\
\text { They become active participants, monitors, consultants and guides when } \\
\text { they work closely with their students' language learning and help } \\
\text { students develop better techniques for learning. }\end{array}$ \\
\hline Ho (1995: 236) & $\begin{array}{l}\text { It is generally agreed that for learners to become autonomous, teachers } \\
\text { must redefine their views about teacher-learner roles. The burden of the } \\
\text { responsibility for such a redefinition should not be assigned solely to } \\
\text { teachers. The teacher also has a role to play in helping learners realize } \\
\text { that they too, must take on responsibility for their learning. }\end{array}$ \\
\hline Voller (1997) & $\begin{array}{l}\text { The language teacher may act as a facilitator who initiates and supports } \\
\text { decision-making processes, a counselor who responds to the ongoing } \\
\text { needs of individuals, and a resource who makes his or her knowledge } \\
\text { and expertise available to the learners when it is needed. }\end{array}$ \\
\hline $\begin{array}{l}\text { Yang (1998: } \\
129-130)\end{array}$ & $\begin{array}{l}\text { Teachers have a role in developing students' learning strategy, which } \\
\text { can facilitate the development of LA. That is to say, teachers should be } \\
\text { responsible for strategy instruction. }\end{array}$ \\
\hline \multirow[t]{6}{*}{ Xu \& Xu (2004) } & Help students build the belief and confidence in autonomous learning; \\
\hline & Guide students to make practical plans; \\
\hline & $\begin{array}{l}\text { Help students to think about the learning strategies and put them into } \\
\text { practice; }\end{array}$ \\
\hline & Make effective use of self-directed center to facilitate LA; \\
\hline & $\begin{array}{l}\text { Encourage more communication between teachers and students via } \\
\text { various channels to monitor the learning process; }\end{array}$ \\
\hline & $\begin{array}{l}\text { Provide more opportunities for students to develop their autonomous } \\
\text { ability. }\end{array}$ \\
\hline
\end{tabular}

As shown in Table 1, teachers' roles in fostering LA are various and complex. It is obvious that teachers who want to foster autonomy of the language learners should not see themselves as directors of classroom learning or as founts of knowledge to be poured into the heads of the learners. Crabbe (1993: 208, cited in Benson, 2004) also reminds that fostering autonomy is not simply a matter we interact with them. It is also a question of how we interact with them. The important question, he argues, is "whether the minute-by-minute classroom practice indirectly fosters or discourages autonomy" by highlighting choices in the curriculum and challenging the learners' ideas about their own roles in the classroom.

\subsection{Relevant Empirical Studies on Teacher's Role in Fostering LA}

Though there have been many research articles on the shifting role that language teachers may play (Knowles, 1975; Higgs, 1988; Nunan, 1993; Ho, 1995; Voller, 1997; Yang, 1998; Aoki, 2000; Xu \& Xu, 2004; Xu, 2007), relevant empirical studies are quite limited.

In order to find out an overall picture about teachers' role perceived by students, $\mathrm{Xu}$ and $\mathrm{Xu}$ (2004) investigated learners' beliefs about teachers' role in developing LA. The following table (Table 2) is about the teachers' role in 
developing LA based on the responses from the students (Xu \& Xu, 2004).

Table 2. Teachers' roles in developing LA from students' perspectives

\begin{tabular}{ll}
\hline General teachers' role & Specific statements \\
\hline Guide (Counselor, Instructor) & $\begin{array}{l}\text { Teaching English learning strategies and methods; teaching } \\
\text { effective ways of learning English autonomously; developing } \\
\text { students' skills in listening and speaking as well as } \\
\text { communicative competence. } \\
\text { Offering necessary enlightenment and assistance; helping } \\
\text { students to make English learning plans and objectives. }\end{array}$ \\
Facilitator (Helper) & $\begin{array}{l}\text { Organizing some communicative activities to get students to } \\
\text { have more chances to practice English. }\end{array}$ \\
Organizer \& Designer & $\begin{array}{l}\text { Making friends with students; able to offer correct } \\
\text { suggestions; willing to communicate with students about } \\
\text { their English learning; working with students to solve their }\end{array}$ \\
Friend, Participant) & learning problems. \\
Inspirator \& Supporter & $\begin{array}{l}\text { Stimulating students' interest and enthusiasm in English } \\
\text { learning; encouraging students to use English; motivating } \\
\text { students to participate in communicative activities; } \\
\text { encouraging students to do more speaking in English. }\end{array}$ \\
Providing students with feedback of their performance in the \\
process of English learning as well as some guidance. \\
Imparting knowledge; providing some references and \\
materials for English learning; introducing some Internet \\
resources. \\
Creating harmonious and active class atmosphere to facilitate \\
students' English studies.
\end{tabular}

As shown in Table 2, teachers' roles in developing LA from students' perspectives are more specific and practical based on students' needs in their development of LA. Just as Xu and Xu (2004) sums up that teachers are expected to play the roles as guide, facilitator, assessor, psychological coordinator, peer cooperator, source of information, learner and researcher.

\section{Conclusion}

In the above part, teacher's role in fostering LA has been elaborated upon from what roles teachers should play and are expected to play from the students' perspective. However, due to the range of the participants being involved, Xu and $\mathrm{Xu}$ (2004) failed to study from the teachers' perspective about the role that they actually play in fostering LA in the classroom teaching.

Therefore, on one hand, this provides the implications for future research. In future research, the focus shall be on the college English teachers' belief and roles they play in fostering LA in their language classroom teaching. Whether the teachers are aware of the significance of developing LA and how they put their knowledge and understanding of it into their teaching practice is the key factor in determining the success of fostering LA. On the other hand, as Smith and Vieira (2009) point out that theoretical and empirical research should be conducted on the competence and conditions for teachers to promote learner autonomy. If language teachers lack of the knowledge or competences to develop learner autonomy, how can they be expected to play their respective roles in promoting learner autonomy. Thus in the future, more empirical research needs to be carried out to explore the knowledge base and conditions for language teachers to promote learner autonomy. 


\section{Acknowledgements}

This research is supported by "the Fundamental Research Funds for the Central Universities" (Grant \# 13QN54).

\section{References}

Allford, D., \& Pachler, N. (2007). Language, autonomy and the new learning environments. Bern: Peter Lang.

Aoki, N. (2000). Affect and the role of teacher in the development of learner autonomy. In J. Arnold (Ed.), Affect in language learning (pp. 142-154). Beijing: Foreign Language Teaching and Research Press.

Benson, P. (1997). The philosophy and politics of learner autonomy. In P. Benson, \& P. Voller (Eds.), Autonomy and independence in language learning (pp.18-34). London: Longman.

Benson, P. (2004). Learner autonomy in the classroom. In D. Nunan (Ed.), Practical English language teaching (pp. 290-308). Beijing: Higher Education Press.

Benson, P. (2005). Teaching and researching autonomy in language learning. Beijing: Foreign Language Teaching and Research Press.

Benson, P. (2006). Autonomy in language teaching and learning. Language Teaching, 40, 21-40. http://dx.doi.org/10.1017/S0261444806003958

Benson, P. (2011). Teaching and researching autonomy (2nd ed.). Harlow: Pearson Education Limited.

Benson, P., \& Voller, P. (Eds.). (1997). Autonomy and independence in language learning. London: Longman.

Broady, E., \& Kenning, Marie-Madeleine. (Eds.). (1996). Promoting learner autonomy in university language teaching. London: Middlesex University Printing Services.

Dickinson, L. (1987). Self-instruction in language learning. Cambridge: Cambridge University Press.

Gardner, D., \& Miller, L. (2002). Establishing self-access: From theory to practice. Shanghai: Shanghai Foreign Language Education Press.

Gremmo, M-J., \& Riley, P. (1995). Autonomy, self-direction and self-access in language teaching and learning: The history of an idea, System, 23(2), 151-164. http://dx.doi.org/10.1016/0346-251X(95)00002-2

Higgs, J. (1988). Planning learning experiences to promote autonomous learning. In D. Boud (Ed.), Developing student autonomy in learning (2nd ed.) (pp. 40-58). London: Kogan.

Higher Education Department of the Ministry of Education. (2007). College English curriculum requirements. Shanghai: Shanghai Foreign Language Education Press.

Ho, J., \& Crookall, D. (1995). Breaking with Chinese cultural traditions: Learner autonomy in English language teaching. System, 23(2), 235-243. http://dx.doi.org/10.1016/0346-251X(95)00011-8

Holec, H. (1981). Autonomy and foreign language learning. Oxford: Pergamon Press.

Jiménez Raya, M., \& Lamb, T. (Eds.). (2008). Pedagogy for autonomy in modern languages education: Theory, practice, and teacher education. Dublin: Authentik.

Knowles, M. (1975). Self-directed learning: A guide for learners and teachers. Chicago: Association Press.

Lamb, T., \& Reinders, H. (Eds.). (2008). Learner and teacher autonomy: Concepts, realities, and responses. Amsterdam/Philadelphia: Benjamins. http://dx.doi.org/10.1075/aals.1

Little, D. (1991). Learner autonomy: Definitions, issues and problems. Dublin: Authentik.

Little, D. (1995). Learning as dialogue: The dependence of learner autonomy on teacher autonomy. System, 23(2), 175-181. http://dx.doi.org/10.1016/0346-251X(95)00006-6

Littlewood, W. (1999). Defining and developing autonomy in East Asian contexts. Applied Linguistics, 20(1), 71-94. http://dx.doi.org/10.1093/applin/20.1.71

Nunan, D. (1993). From learning-centeredness to learner-centeredness. Applied Language Learning, (4), 1-18.

Shu, D. F., \& Zhuang, Z. X. (2008). Modern foreign language teaching: Theories, practice and approaches. Shanghai: Shanghai Foreign Language Education Press.

Sinclair, B., \& Lamb, T. (Eds.). (2000). Learner autonomy, teacher autonomy: Future directions. London: Longman. 
Smith, R. C. (2008). Learner autonomy. ELT Journal, 62(4), 395-397. http://dx.doi.org/10.1093/elt/ccn038

Smith, R., \& Vieira, F. (2009). Teacher education for learner autonomy: Building a knowledge base. Innovation in Language learning and Teaching, 3(3), 215-220. http://dx.doi.org/10.1080/17501220903404434

Voller, P. (1997). Does the teacher have a role in autonomous language learning? In P. Benson, \& P. Voller (Eds.), Autonomy and independence in language learning (pp. 98-113). London: Longman.

$\mathrm{Xu}, \mathrm{J} . \mathrm{F}$. (2006). The theory and practice of modern foreign language teaching. Wuhan: Huazhong University of Science and Technology Press.

$\mathrm{Xu}$, J. F. (2007). The theory and practice of university foreign language autonomous learning. Beijing: China Social Sciences Publishing House.

Xu, J. F., \& Xu. L. (2004). Exploring College English teachers' roles in the autonomous learning mode. Higher Education Research, 3, 77-79.

Yang, N. (1998). Exploring a new role for teachers: promoting learner autonomy. System, 26, $127-135$. http://dx.doi.org/10.1016/S0346-251X(97)00069-9 